\title{
Carbon Isotope Ratios of Great Plains Soils and in Wheat-Fallow Systems
}

\author{
R. F. Follett,* E. A. Paul, S. W. Leavitt, A. D. Halvorson, D. Lyon, and G. A. Peterson
}

\begin{abstract}
The purposes of this study were to improve knowledge of regional vegetation patterns of $C_{3}$ and $C_{4}$ plants in the North American Great Plains and to use $\delta^{13} \mathrm{C}$ methodology and long-term research sites to determine contributions of small-grain crops to total soil organic carbon (SOC) now present. Archived and recent soil samples were used. Detailed soil sampling was in 1993 at long-term sites near Akron, CO, and Sidney, NE. After soil sieving, drying, and deliming, SOC and $\delta^{13} \mathrm{C}$ were determined using an antomated $\mathrm{C} / \mathrm{N}$ analyzer interfaced to an isotope-ratio mass spectrometer. Yield records from long-term experimental sites were used to estimate the amount of $C_{3}$ plant residue $\mathrm{C}$ returned to the soil. Results from $\delta^{13} \mathrm{C}$ analyses of soils from near Waldheim, Saskatchewan, to Big Springs, TX, showed a strong north to south decrease in SOC derived from $\mathrm{C}_{3}$ plants and a corresponding increase from $C_{4}$ plants. The $\delta^{13} \mathrm{C}$ analyses gave evidence that $\mathrm{C}_{3}$ plant residue $\mathrm{C}$ (possibly from shrubs) is increasing at the Big Springs, TX, and Lawton, $O K$, sites. Also, $\delta^{13} \mathrm{C}$ analyses of subsoil and topsoil layers shows evidence of a regional shift to more $C_{3}$ species, possibly because of a cooler climate during the past few hundreds to thousands of years. Data from long-term research sites indicate that the efficiency of incorporation of small-grain crop residue $\mathrm{C}$ was about 5.4\% during $84 \mathrm{yr}$ at Akron, $\mathrm{CO}$, and about $10.5 \%$ during 20 yr at Sidney, NE. The ${ }^{14} \mathrm{C}$ age of the SOC at 0- to 10-cm depth was $193 \mathrm{yr}$ and at 30 to $45 \mathrm{~cm}$ was $4000 \mathrm{yr}$; ${ }^{14} \mathrm{C}$ age of nonhydrolyzable $\mathrm{C}$ was 2000 and 7000 yr for these same two respective depths. Natural partitioning of the ${ }^{13} \mathrm{C}$ isotope by the photosynthetic pathways of $\mathrm{C}_{3}$ and $\mathrm{C}_{4}$ plants provides a potentially powerful tool to study $\mathrm{SOC}$ dynamics at both regional and local scales.
\end{abstract}

$\mathrm{T}$ He photosynthetic pathWays of $\mathrm{C}_{3}$ and $\mathrm{C}_{4}$ plants discriminate differently for the naturally occurring ${ }^{13} \mathrm{C}$ isotope so that the ${ }^{13} \mathrm{C} /{ }^{12} \mathrm{C}$ isotope ratio that results can be used to partition soil organic matter (SOM) as to its origin. Where plants with different photosynthetic pathways have occurred in a time sequence in either managed or unmanaged systems, or occur concurrently in the same system, SOM contains two isotopically different sources of C (Martin et al., 1990; Balesdent and Balabane, 1992; Gregorich et al., 1995a, 1996; Hsieh, 1996). Use of these two isotopically different SOM sources of C allowed Wedin et al. (1995) to suggest that isotopic shifts during the decomposition of litter from four perennial grasses (both $\mathrm{C}_{3}$ and $\mathrm{C}_{4}$ species) are caused by the incorporation of new $\mathrm{C}$ from SOM matter into the litter by microbial decomposers. Also, by using ${ }^{13} \mathrm{C} /{ }^{12} \mathrm{C}$ isotope ratio methodology, Gregorich et al. (1995b) was able to determine that, following $25 \mathrm{yr}$ of continuous corn (Zea mays L.) grown on a forest soil in eastern Ontario, about $30 \%$ of the SOC in the plow

R.F. Follett, USDA-ARS, Ft. Collins, CO; E.A. Paul, Crop and Soil Sciences, Michigan State Univ., East Lansing, MI; S.W. Leavitt, Lab. of Tree Ring Research, Univ. of Arizona, Tucson, AZ; A.D. Halvorson, USDA-ARS, Mandan, ND; D. Lyon, Panhandle Research and Extension Center, Univ. of Nebraska, Scottsbluff, NE; G.A. Peterson, Soil and Crop Sciences, Colorado State Univ., Fort Collins, CO. Received 15 Dec. 1995. *Corresponding author.

Published in Soil Sci. Soc. Am. J. 61:1068-1077 (1997). layer $(0-27 \mathrm{~cm})$ was derived from corn. Gregorich et al. (1996) also used ${ }^{13} \mathrm{C}$ abundance methods to account for the higher amount of $\mathrm{C}_{4}$ plant derived $\mathrm{C}$ in long-term $\mathrm{N}$-fertilized soils compared with unfertilized soils.

Equation [1] expresses the ${ }^{13} \mathrm{C} /{ }^{12} \mathrm{C}$ ratio as $\delta^{13} \mathrm{C}$, which has "per mil" (\%) units. By convention, $\delta^{13} \mathrm{C}$ values are expressed relative to a $\mathrm{CaCO}_{3}$ standard known as $\mathrm{PDB}$ from the Cretaceous Pee Dee formation in South Carolina (Boutton, 1991). The sign of the $\delta^{13} \mathrm{C}$ value indicates whether the sample has a higher or lower ${ }^{13} \mathrm{C} /{ }^{12} \mathrm{C}$ isotope ratio than PDB.

$$
\delta^{13} \mathrm{C}(\% \mathrm{o})=\frac{\left({ }^{13} \mathrm{C} /{ }^{12} \mathrm{C}\right) \text { sample }-1}{\left({ }^{13} \mathrm{C} /{ }^{12} \mathrm{C}\right) \text { reference }} \times 1000
$$

Enough published information and knowledge of native plant vegetation for the North American Great Plains now exist to predict that use of $\delta^{13} \mathrm{C}$ data will become a powerful tool for studying SOM dynamics. However, rapid and precise analyses of adequate numbers of samples for meaningful interpretations are increasingly important. An objective of this study is to assess the potential for using $\delta^{13} \mathrm{C}$ analyses to improve knowledge of regional vegetation patterns of $\mathrm{C}_{3}$ and $\mathrm{C}_{4}$ plants in the historic grassland in the North American Great Plains and to assess the contributions of $\mathrm{C}_{3}$ and $\mathrm{C}_{4}$ plants to SOM. Another objective is to evaluate the usefulness of $\delta^{13} \mathrm{C}$ methodology and sample collection from long-term research sites, including using existing crop and soil records (which are sometimes minimal) for assessing soil $\mathrm{C}$ dynamics and the contribution of small-grain crop residue $\mathrm{C}$ to SOM now present in these soils.

\section{METHODS AND MATERIALS}

\section{Sample Collection}

Archived soil samples, collected in 1947 to 1949 from native grasslands (Haas et al., 1957), were obtained from storage at the Northern Great Plains Research Center in Mandan, ND, for $\delta^{13} \mathrm{C}$ and SOC analyses of U.S. sites (except at Sidney, $\mathrm{NE}$ ). Soils from some sites were also ${ }^{14} \mathrm{C}$ dated and the results reported by Paul et al. (1997). These archived samples are important to this study because of the documentation that accompanied their collection (Haas et al., 1957; Paul et al., 1997) and their broad regional representation of historic grassland soils. Data from Canadian sites were collected earlier and data presented by Martel (1972) and Martel and Paul (1974).

Additional soil samples were collected in April of 1993 from the Akron, CO, and Sidney, NE, research sites (native grassland vs. long-term wheat [Triticum aestivum L.]-fallow cultivation) by use of a hydraulic coring system using 3.5 - and $3.8-\mathrm{cm}$-diam. tubes, respectively. Native prairie vegetation was estimated (see also Table 1) to be a mixture of about 65 to $70 \% \mathrm{C}_{4}$ and 30 to $35 \% \mathrm{C}_{3}$ plants at the Akron, CO, and Sidney, NE, study sites. This vegetation was replaced with winter wheat (i.e., a $C_{3}$ crop). Lapsed time since the transition to $C_{3}$

Abbreviations: SOC, soil organic carbon; SOM, soil organic matter; $\mathrm{BP}$, before present. 
crops at the Akron and Sidney sites and our 1993 sample collection is 84 and $20 \mathrm{yr}$, respectively.

The Akron site is on a Weld loam, a fine, montmorillonitic, mesic Aridic Paleustoll, with $<1 \%$ slope. The Sidney site is on a Duroc loam, a fine-silty, mixed, mesic Pachic Haplustoll with $<1 \%$ slope. Each sample was a composite of three soil cores per replicate for each treatment; soil cores were collected along the length of each cultivated plot. At both Akron and Sidney, three replicated composites of soil samples were collected from an adjacent native prairie pasture. In addition, at the Sidney site, a replicated sod-plot treatment was sampled. The sod plots were randomized within the cultivated plots as part of the original layout of the research area (Fenster and Peterson, 1979), but never cultivated. Grass species present in the sod plots included native wheat grasses (Agropyron spp.), which are cool-season $C_{3}$ plants. Species counts or other additional measurements of species densities were not made because it was early April and contributions of individual plant species to total annual plant biomass production is difficult to determine during this dormant period and following overwintering of the plant material. Thus, we collected random "grab" samples of the aboveground biomass (clipped at $\approx 1$-cm height) for measuring $\delta^{13} \mathrm{C}$. The measured $\delta^{13} \mathrm{C}$ was then used to estimate the relative amounts of aboveground biomass from $\mathrm{C}_{3}$ vs. $\mathrm{C}_{4}$ plant tissue.

\section{Laboratory Preparation and Analysis}

Plant material ( $\geq 2 \mathrm{~mm}$ ) was sieved from the soil samples before air drying. Soil carbonates were removed by addition of $100 \mathrm{~mL}$ of $0.03 \mathrm{M} \mathrm{H}_{3} \mathrm{PO}_{4}$ to 5 to $6 \mathrm{~g}$ of soil and shaking for $1 \mathrm{~h}$. The procedure was repeated until the $\mathrm{pH}$ of the soil solution remained within $0.2 \mathrm{pH}$ unit of that of the original acid solution. These delimed soil samples were oven dried at $55^{\circ} \mathrm{C}$, ground to pass a $180-\mu \mathrm{m}$ screen, and analyzed for total SOC and $\delta^{13} \mathrm{C}$. Winter wheat straw and corn stover were also collected, ground to pass a $150-\mu \mathrm{m}$ screen, and analyzed for $\delta^{13} \mathrm{C}$. Soil from Akron, $\mathrm{CO}$, and samples of winter wheat and corn stover were hydrolyzed with hot, $6 \mathrm{M} \mathrm{HCl}$; the nonhydrolyzable fraction was analyzed for $\mathrm{C}$ content and $\delta^{13} \mathrm{C}$. Sidney, $\mathrm{NE}$, soil samples were not hydrolyzed. Total SOC and $\delta^{13} \mathrm{C}$ were determined using a Carlo Erba $\mathrm{C} / \mathrm{N}$ analyzer (Haake Buchler Instruments, Saddle Brook, $\mathrm{NJ}^{\prime}$ ) interfaced to a Tracer mass isotope-ratio mass spectrometer (Europa Scientific Ltd., Crewe, England). Meaningful measurements of $\delta^{13} \mathrm{C}$ require reproducibility and high precision and until recently the suitability of automated nitrogen and carbon analysismass spectrometry (ANCA-MS) for this procedure for soil samples had not been extensively tested. Recent tests of ANCA-MS were done on soils having a range in $\delta^{13} \mathrm{C}$ of -13 to $-26 \%$ (Barrie et al., 1995). Analytical standard deviations of $\leq 0.1 \%$ were obtained even though soil $\mathrm{C}$ contents were from 7 to $29 \mathrm{~g} \mathrm{~kg}^{-1}$. We obtained essentially the same $\delta^{13} \mathrm{C}$ values and standard deviations when analyzing the same soils.

\section{Cropping - Residue Inputs}

Historical yield records for long-term experimental plots were obtained for both the Akron, $\mathrm{CO}$ (Brandon and $\mathrm{Ma}$ thews, 1944; Greb, 1983; US. Department of Agriculture, 1972-1994), and the Sidney, NE (D.J. Lyon, 1994, personal communication), sites for estimating amounts and type of crop-residue $\mathrm{C}$ returned to the soil at both locations. The linear form of the equation by Balesdent et al. (1988) was

\footnotetext{
'Trade and company names are included for the benefit of the reader and do not imply endorsement or preferential treatment of the product by the authors or the USDA.
}

transformed into Eq. [2] and used to calculate changes in fraction of SOC resulting from growth of a monoculture of $\mathrm{C}_{3}$ wheat on native soil developed from mostly $\mathrm{C}_{4}$ grasses.

$$
\begin{aligned}
& \% \text { soil } \mathrm{C} \text { from wheat }= \\
& \qquad \frac{\delta^{13} \mathrm{C} \text { wheat soil }-\delta^{13} \mathrm{C} \text { native soil }}{\delta^{13} \mathrm{C} \text { wheat }-\delta^{13} \mathrm{C} \text { native soil }}
\end{aligned}
$$

Nearly all historic records show grain yields, but not crop residue production records. Therefore, where crop-residue records were unavailable, quantities of aboveground residues were estimated by multiplying total grain production by a grain to residue weight ratio (U.S. Department of Agriculture, 1978). Belowground crop residue (root) estimates can be based on a grain to root ratio (Wilhelm et al., 1982) or an aboveground crop residue to root ratio (Buyanovsky et al., 1987; Buyanovsky and Wagner, 1986, 1987, 1995). Input of C by weeds was estimated as a fraction (0.35) of crop straw plus root production (Greb, 1983; K. Gross, 1996, personal communication). All plant residues were assumed to be $40 \%$ C on a dry-weight basis (Parr and Papendick, 1978).

\section{RESULTS AND DISCUSSION Patterns of Carbon-13 Natural Abundance Measured in Great Plains Soils}

Archived soil samples, collected under native grassland, were analyzed from sites extending from near Waldheim, Saskatchewan, to near Big Springs, TX (Fig. 1). These sites provide a broad regional overview of the historical patterns of $C_{3}$ and $C_{4}$ vegetation on the resulting $\delta^{13} \mathrm{C}$ observed in SOC (Table 1). Measured $\delta^{13} \mathrm{C}$ values from north to south became less negative and thus show a regional shift from predominately $C_{3}$ to $C_{4}$ vegetation. This pattern occurred with both surface and subsurface soil samples. However, the trend for $\delta^{13} \mathrm{C}$ to become less negative from north to south reversed for soils collected from Lawton, OK, and Big Springs, TX, sites, especially for surface soils and to a lesser degree subsurface soils.

Surface soils contained more SOC than subsurface soils (Table 1). Although SOC decreased from north to south, our sample variation is probably too great for conclusions about SOC levels in Great Plains soils. A more systematic sampling should reveal SOC trends resulting from precipitation and temperature gradients as originally described by Jenny (1941).

Soil samples from Havre, MT, had a more negative mean $\delta^{13} \mathrm{C}$ in the subsurface than in the surface soil. Samples from Lawton, OK, and Big Springs, TX, had $\delta^{13} \mathrm{C}$ values 3.4 and $2.0 \%$ less negative in the subsurface than in the surface soil. The $\delta^{13} \mathrm{C}$ signature of SOC should reflect $\mathrm{C}$ inputs from contemporary vegetation. As described by Kelly et al. (1993), we used a simple mixing model that assumed average isotope composition $\left(\delta^{13} \mathrm{C}\right)$ for $\mathrm{C}_{3}$ and $\mathrm{C}_{4}$ plants to be -26.0 and $-12.0 \%$, respectively. The values used by Kelly et al. (1993) are reasonable based on our own analyses of various $C_{3}$ and $\mathrm{C}_{4}$ plant materials. The mean $\delta^{13} \mathrm{C}( \pm 1$ standard deviation) that we measured for six $\mathrm{C}_{3}$ plant samples was $-25.36 \pm 0.96 \%$ and for five $C_{4}$ plant samples it was $-11.48 \pm 1.59 \%$. 




Fig. 1. Sampling sites for measurement of patterns of $\delta^{13} \mathrm{C}$ under native grasslands of the North American Great Plains.

Using the mixing model of Kelly et al. (1993), the calculated fraction of SOM originating from $\mathrm{C}_{3}$ plants decreased from north to south, while that from $\mathrm{C}_{4}$ plants increased. This trend reverses for the Lawton, $\mathrm{OK}$, and Big Springs, TX, sites. Lawton had SOM showing a contribution of $40 \% \mathrm{C}_{3}$ plant residues in the surface (0-15-cm depth) and 16\% in the subsurface soil (15-30$\mathrm{cm}$ depth); Big Springs showed $42 \% \mathrm{C}_{3}$ in the surface and $28 \%$ in the subsurface soil (Table 1). Possibly these observations can be attributed to plant species shifts. The $\delta^{13} \mathrm{C}$ trends for Lawton and Big Springs may reflect fairly recent historical vegetation changes, such as mesquite (Prosopis spp.) or other $\mathrm{C}_{3}$ species migrating into these native grassland areas. Descriptions of these two sites in 1947 to 1949 (Haas et al., 1957) indicate that tall grasses were the native vegetation at Lawton and that short grasses and mesquite were the native vegetation at Big Springs. Based on mean annual temperatures reported by Haas et al. (1957), soils at both Lawton and Big Springs are thermic (Soil Survey Staff, 1994). Thus, native tall and short grasses reported by Haas et al. (1957) should be mostly warm-season $C_{4}$ grasses that would not result in the observed $\delta^{13} \mathrm{C}$ values for these two sites. However, mesquite and other shrubby species are $\mathrm{C}_{3}$ plants and, if present in sufficient density and for sufficient time, would cause a more negative $\delta^{13} \mathrm{C}$ signature in the SOC.

Average $\delta^{13} \mathrm{C}$ of SOC for the remaining eight sites, where data were collected from both depths, was $0.60 \pm$ $0.75 \%$ more negative in the surface than in the subsurface soil, a change in $\delta^{13} \mathrm{C}$ equivalent to about a $5 \%$ shift from $\mathrm{C}_{4}$ to $\mathrm{C}_{3}$ plant residues. Radiocarbon dating of SOC of the subsurface soils from Mandan, Akron, Hays, and Dalhart resulted in ages of 2150,2611, 1215, and $1380 \mathrm{yr}$, respectively (Paul et al., 1997). The respective ages of surface soils for these four sites were 1200, 0 , 645 , and $930 \mathrm{yr}$. The $\delta^{13} \mathrm{C}$ measured in the surface soil compared with that measured in the subsurface soil for these same sites was $1.0,2.1,0.9$, and $0.8 \%$ more negative, respectively. Consequently, the calculated shift of the $\delta^{13} \mathrm{C}$ signature from that of a $\mathrm{C}_{4}$ to a $\mathrm{C}_{3}$ plant, between the subsurface and surface soil, for these four sites were greatest where the ${ }^{14} \mathrm{C}$ ages of the subsurface soil were oldest and where there was the largest difference in ${ }^{14} \mathrm{C}$ age between the surface and subsurface soil. Besides the older age of subsurface soils, for sites where ${ }^{14} \mathrm{C}$ dating was done, there is a broad regional consistency of a more negative $\delta^{13} \mathrm{C}$ in surface than in subsurface soils for nearly all sites in this study (Table 1). 
Table 1. Surface- and subsurface-soil organic $C$ and $\delta^{13} C$ content and calculated percentage of $C_{3}$ vs. $C_{4}$ plants for the Great Plains.

\begin{tabular}{|c|c|c|c|c|c|c|c|}
\hline \multirow[b]{2}{*}{ Location } & \multirow[b]{2}{*}{ Depth } & \multicolumn{3}{|c|}{ Soil organic C } & \multirow[b]{2}{*}{ \pm SD } & \multirow[b]{2}{*}{$\mathbf{C}_{3}$} & \multirow[b]{2}{*}{$\mathbf{C}_{4}^{\dagger}$} \\
\hline & & $\delta^{13} \mathrm{C}$ & \pm SD & Conc. & & & \\
\hline & cm & \multicolumn{2}{|c|}{${ }_{-1}=$} & \multicolumn{2}{|c|}{$\longrightarrow \mathbf{g ~ k g}^{-1}$} & \multicolumn{2}{|c|}{$\%$} \\
\hline \multicolumn{8}{|c|}{ Surface soils } \\
\hline Waldheim, SK & 0-15 & -25.1 & 0.07 & 24.0 & 4.2 & 93.2 & 6.8 \\
\hline Quinton, SK & $0-15$ & -25.5 & 0.99 & 59.0 & 7.1 & 96.1 & 3.9 \\
\hline Matador, SK & $0-8$ & -25.0 & - & 57.0 & - & 92.9 & 7.1 \\
\hline Havre, MT & $0-15$ & -20.4 & 0.52 & 15.5 & 1.4 & 59.9 & 40.1 \\
\hline Mandan, ND & 0-15 & -20.2 & 0.70 & 28.4 & 1.8 & 58.9 & 41.1 \\
\hline Archer, WY & $0-15$ & -18.0 & 0.60 & 12.7 & 0.7 & 42.9 & 57.1 \\
\hline Sidney, NE & $0-15$ & -16.2 & 1.23 & 17.8 & 3.2 & 30.0 & 70.0 \\
\hline Akron, Co & $0-15$ & -16.9 & 0.40 & 13.5 & 0.9 & 35.1 & 64.9 \\
\hline Hays, KS & $0-15$ & -15.4 & 0.21 & 22.9 & 1.9 & 24.4 & 75.6 \\
\hline Dalhart, TX & $0-15$ & -14.9 & 0.34 & 6.5 & 1.0 & 20.8 & 79.2 \\
\hline Lawton, OK & $0-15$ & -17.7 & 0.71 & 17.9 & 1.1 & 40.5 & 59.5 \\
\hline Big Springs, TX & $0-15$ & -17.9 & 0.29 & 5.5 & 0.5 & 42.5 & 57.5 \\
\hline \multicolumn{8}{|c|}{ Subsurface soils } \\
\hline Waldheim, SK & $15-22$ & - & - & 6.2 & - & - & - \\
\hline Quinton, SK & 34-55 & -25.3 & 0.49 & 6.6 & - & 94.6 & 5.4 \\
\hline Matador, SK & - & - & - & - & - & - & - \\
\hline Havre, MT & $15-30$ & -21.0 & 0.93 & 10.1 & 1.2 & 64.1 & 35.9 \\
\hline Mandan, ND & $15-30$ & -19.2 & 0.51 & 17.4 & 2.3 & 51.8 & 48.3 \\
\hline Archer, WY & $15-30$ & -17.8 & 0.28 & 8.3 & 1.2 & 41.6 & 58.4 \\
\hline Sidney, NE & $15-30$ & -15.8 & 1.25 & 10.4 & 2.5 & 27.2 & $\mathbf{7 2 . 8}$ \\
\hline Akron, CO & $15-30$ & -14.8 & 0.39 & 8.2 & 0.5 & 20.2 & 79.8 \\
\hline Hays, KS & $15-30$ & -14.5 & 0.44 & 12.2 & 1.0 & 17.7 & 82.3 \\
\hline Dalhart, TX & $15-30$ & -14.1 & 0.34 & 5.4 & 0.9 & 15.2 & 84.8 \\
\hline Lawton, OK & $15-30$ & -14.3 & 0.67 & 11.3 & 0.4 & 16.5 & 83.5 \\
\hline Big Springs, TX & 15-30 & -15.9 & $\mathbf{0 . 3 3}$ & 4.6 & 0.6 & 27.5 & 72.5 \\
\hline
\end{tabular}

$\dagger$ A simple mixing equation with the average isotope composition $\left(\delta^{13} \mathrm{C}\right)$ for $C_{3}$ and $C_{4}$ plants assumed to be -26.0 and $-12.0 \%$, respectively.

We now consider whether the younger $\mathrm{C}$ and more negative $\delta^{13} \mathrm{C}$ observed in more recent SOM results from a vegetative shift to $C_{3}$ plants that, in turn, has resulted from a cooler climate during the past few hundreds to thousands of years. Peat types in northwestern Europe indicate that the climate became cooler and wetter since about 7000 yr before present (BP) (Flint, 1947, 1967); pollen studies suggest nearly the same climatic succession in North America. Recent vegetation and other climate indices indicate that the paleoclimate supported spruce trees in northeast Kansas from about 18000 to 13000 yr BP (Wayne, 1991). Post-glacial warming was slow and progressed from west to east and from south to north. The modern forest-prairie ecotone in northeast Kansas has occupied the same position since about 5000 yr BP (Kurmann, 1985). Reversal of warming of the post-glacial, to become cooler and wetter, is reported to have probably occurred about 5000 (Wayne, 1991; Kelly et al., 1993) to 7000 yr BP (Wright, 1970, 1983), causing the prairie to withdraw to the west.

Another explanation of $\delta^{13} \mathrm{C}$ differences in surface and subsurface soils might be that $\delta^{13} \mathrm{C}$ in atmospheric $\mathrm{CO}_{2}$ became more negative with a subsequent effect on $\delta^{13} \mathrm{C}$ of plant residue entering the soil. However, there does not appear to be a shift prior to the industrial age. Toolin and Eastoe (1993) measured essentially no change in $\delta^{13} \mathrm{C}$ of samples of $\mathrm{C}_{4}$ Setaria species from pack-rat middens, herbarium specimens, and modern plants between 12600 and $1800 \mathrm{yr} \mathrm{BP}$. Other $\mathrm{C}_{4}$ plant material (Atriplex confertifolia L.) from pack-rat middens shows essentially no change in atmospheric $\delta^{13} \mathrm{C}$ for the past $15000 \mathrm{yr}$ (Marino and McElroy, 1991; Marino et al., 1992). Neither has $\delta^{13} \mathrm{C}$ of $\mathrm{CO}_{2}$ in polar ice cores changed materially (Leuenberger et al., 1992). During the last glaciation, $\delta^{13} \mathrm{C}$ was $0.3 \pm 0.2 \%$ more negative than preindustrial $\delta^{13} \mathrm{C}$ of $-6.5 \%$. Modern regional and global $\delta^{13} \mathrm{C}$ of atmospheric $\mathrm{CO}_{2}$ are -8.2 and $-7.7 \%$, respectively (Toolin and Eastoe, 1993).

Other possible explanations for a $\delta^{13} \mathrm{C}$ shift in SOC include: (i) isotope partitioning by microorganisms with respired $\mathrm{CO}_{2}$ depleted in ${ }^{13} \mathrm{C}$ and the $\delta^{13} \mathrm{C}$ of microbial products becoming less negative (Mary et al., 1992), (ii) different mineralization rates of cellulose and lignin that have naturally different degrees of ${ }^{13} \mathrm{C}$ depletion, and (iii) local and general climatic variations with time. Overall, the above sources of variations could affect interpretation of our data, but did not exceed $1.0 \%$ o for soil studied by Balesdent et al. (1987). Thus, a vegetative shift toward more $C_{3}$ species appears to be the most likely explanation for the observed $\delta^{13} \mathrm{C}$ differences between surface and subsurface soils.

\section{Long-Term Site Studies of Carbon Changes} Akron, Colorado (1909-1993)

The 1947 samples from Akron were collected at 0- to 15- and 15- to 30-cm depths; therefore, our calculations proportioned the 1993 data (Table 2) to these same depths. Because of no statistical difference between the replicated $\delta^{13} \mathrm{C}$ and SOC values of 1947 vs. 1993 native samples, we averaged their values. This resulted in $\delta^{13} \mathrm{C}$ values of $-16.41 \pm 0.62 \%$ or the 0 - to $15-\mathrm{cm}$ depth (surface soil) and $-14.85 \pm 0.30 \%$ or the 15 - to 30 $\mathrm{cm}$ depth (subsurface soil). The SOC concentrations averaged $13.5 \pm 0.6 \mathrm{~g} \mathrm{~kg}^{-1}$ in the surface and $8.8 \pm 0.8$ $\mathrm{g} \mathrm{kg}^{-1}$ in the subsurface soil. The $\delta^{13} \mathrm{C}$ for 1947 samples from the cultivated treatment averaged $-16.39 \pm 0.10 \%$ for the surface and $-15.48 \pm 0.20 \%$ for the subsurface 
Table 2. Total organic $\mathrm{C}$ and $\delta^{13} \mathrm{C}$ of native and cultivated soil from $A$ kron, Co, and nonhydrolyzable soil $\mathrm{C}$ for 1993 samples, and of winter wheat (TAM 107) straw and corn (Pioneer 3732) stover and their nonhydrolyzable $\mathrm{C}$.

\begin{tabular}{|c|c|c|c|c|c|}
\hline \multirow[b]{2}{*}{ Depth } & \multicolumn{2}{|c|}{ Total soil } & \multicolumn{3}{|c|}{ Nonhydrolyzable } \\
\hline & $\begin{array}{c}\text { Organic C } \\
\text { cone. }\end{array}$ & $\delta^{13} \mathbf{C}$ & $\begin{array}{l}\text { Fractionation } \\
\text { of total soil C }\end{array}$ & $\boldsymbol{\delta}^{13} \mathbf{C}$ & Difference \\
\hline $\mathrm{cm}$ & $\mathrm{g} \mathrm{kg}^{-1}$ & $\%$ & $\%$ & 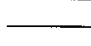 & $\%$ \\
\hline \multicolumn{6}{|c|}{ Native soil } \\
\hline $0-10$ & 14.7 & -16.1 & 55.9 & -19.1 & -3.0 \\
\hline $10-20$ & 10.1 & $-\mathbf{1 5 . 3}$ & 45.3 & $-\mathbf{1 8 . 8}$ & -3.5 \\
\hline $20-30$ & 9.2 & -14.7 & 44.5 & -20.3 & -5.6 \\
\hline $30-60$ & 5.4 & -14.6 & 39.4 & -22.3 & -7.7 \\
\hline $60-90$ & - & - & - & - & - \\
\hline $90-120$ & - & - & - & - & - \\
\hline \multicolumn{6}{|c|}{ Cultivated soil } \\
\hline $0-10$ & 8.8 & -19.3 & 59.1 & -20.9 & -1.6 \\
\hline 10-20 & 7.2 & $-\mathbf{1 7 . 3}$ & 54.2 & -20.3 & $-\overline{3.0}$ \\
\hline $20-30$ & 6.0 & -15.9 & 48.5 & -19.8 & -3.9 \\
\hline $30-60$ & 6.7 & -16.8 & 49.9 & -20.2 & -3.4 \\
\hline $60-90$ & 3.5 & -18.0 & 45.3 & -22.2 & -4.2 \\
\hline $90-120$ & 1.8 & -15.4 & 51.1 & -22.0 & -6.6 \\
\hline \multicolumn{6}{|c|}{ Plant material } \\
\hline Wheat & 433 & & & -27.3 & -1.1 \\
\hline Corn & 443 & $-\mathbf{1 3 . 0}$ & 52.0 & $-\mathbf{1 5 . 0}$ & -2.5 \\
\hline
\end{tabular}

soil. Corresponding values for 1993 soil samples from the cultivated treatment averaged $-18.85 \pm 0.10 \%$ for the surface and $-16.24 \pm 0.20 \%$ for the subsurface soil. Because no data is available and to be able to compare weight of $\mathrm{C}$ for 1909 and 1947, we assumed that bulk densities of the 1909 native site and the 1947 native and cultivated sites were the same as those measured in 1993 (native site: $1.27 \pm 0.07$ and $1.32 \pm 0.08 \mathrm{~g} \mathrm{~cm}^{-3}$; and cultivated site: $1.25 \pm 0.09$ and $1.32 \pm 0.07 \mathrm{~g} \mathrm{~cm}^{-3}$ as interpolated for the $0-15$-and $15-30-\mathrm{cm}$ depths, respectively).

Information for Fig. 2 used the above data. Calculations of weight of SOC are based on C concentration and soil bulk density of the soil layer and show that by 1947 cultivation had decreased the SOC of the 0 - to 15 $\mathrm{cm}$ layer by $32 \%$ and of the $15-$ to $30-\mathrm{cm}$ layer by $8 \%$. Total decrease in SOC from 1909 to 1993 was calculated to be $39 \%$ in the surface and of $28 \%$ in the subsurface soil. The $\delta^{13} \mathrm{C}$ calculations (Eq. [2]) show that by 1993, in the cultivated soil, original native SOC had dropped to 46 and $63 \%$ of that present originally in the surface and subsurface soils, respectively. For the top $30 \mathrm{~cm}$, average annual rates of loss of total and native SOC were 260 and $280 \mathrm{~kg} \mathrm{C} \mathrm{ha}^{-1}$ from 1909 to 1947 , but decreased to an average annual rate of 120 and $220 \mathrm{~kg}$ $\mathrm{C} \mathrm{ha}^{-1}$ between 1947 and 1993. By 1993, SOC derived from $\mathrm{C}_{3}$ plant (wheat) residues was about $24 \%$ of the remaining SOC in the $0-$ to $15-\mathrm{cm}$ depth and $12 \%$ of that remaining in the $15-$ to $30-\mathrm{cm}$ depth; these amounts represent $3900 \mathrm{~kg} \mathrm{C} \mathrm{ha}^{-1}$ in the 0 - to $15-\mathrm{cm}$ depth and $1500 \mathrm{~kg} \mathrm{ha}^{-1}$ of $\mathrm{C}$ in the $15-$ to $30-\mathrm{cm}$ depth. Essentially all of the $3900 \mathrm{~kg} \mathrm{ha}^{-1}$ of SOC derived from $\mathrm{C}_{3}$ plants in the $0-$ to $15-\mathrm{cm}$ depth accumulated after 1947. Average annual rate of addition of SOC derived from $\mathrm{C}_{3}$ plants to the top $30 \mathrm{~cm}$ of soil increased from about 20 to about $100 \mathrm{~kg} \mathrm{C} \mathrm{ha}^{-1}$ between 1909 to 1947 and 1947 to 1993 .
Wheat yields have been recorded at Akron since 1909 (Table 3). Plant $\mathrm{C}$ inputs include the straw, roots, and weeds. Reported yields for each of a series of management periods are divided by two to account for the wheat-fallow system. Annual yields following initial cultivation were about $1130 \mathrm{~kg} \mathrm{ha}^{-1}$. These then dropped to an average of $540 \mathrm{~kg} \mathrm{ha}^{-1}$ followed by a slow increase to the present $3090 \mathrm{~kg} \mathrm{ha}^{-1}$ every $2 \mathrm{yr}$. An on-site straw to grain ratio of 1.7 was determined for these calculations. Table 3 considers that until the advent of combine harvesting, assumed to have occurred by $1947,67 \%$ of the straw was removed by threshing and not returned to the soil. Thereafter, all straw was assumed to be returned to the soil.

Root weights were measured by Wilhelm et al. (1982) as about $20 \%$ of grain weight at harvest. Use of ${ }^{14} \mathrm{C}$ tracer and other techniques show substantial rhizodeposition and root turnover prior to harvest (Buyanovsky and Wagner, 1986, 1995). We therefore used similar values to those of Swinnen et al. (1995) and Buyanovsky and Wagner (1986, 1987, 1995). Root C inputs were calculated as grain weight times 0.57 . Weeds are even more variable than roots. Reported fall weed growth at Akron, CO, for 1969 to 1972 was 70,650 , and $1140 \mathrm{~kg}$ $\mathrm{ha}^{-1}$ (dry-wt. basis) with weed control treatments of double fall sweep, single fall sweep, and spring disk, respectively (Greb, 1983); most weed growth was in the noncropped period. We computed weed-C inputs to equal $35 \%$ of straw plus crop root inputs through 1947. Since 1947 , we estimated weed inputs to be $25 \%$ of straw plus crop-root input because of improved herbicides and tillage. These values generally agree with other agroecological measurements at other sites (K. Gross, 1996, personal communication). All weeds were assumed to be of $\mathrm{C}_{3}$ origin.

Knowledge of SOC attributable to native soil or derived from plant residues returned to the soil after cultivation began allows calculation of the percentage of plant residue $\mathrm{C}$ remaining in the soil for different time periods. Input of residue $\mathrm{C}$ at Akron was about 17000 $\mathrm{kg} \mathrm{ha}^{-1}$ from 1909 to 1947 (Table 3). Use of Eq. [2] showed that about $800 \mathrm{~kg} \mathrm{ha}^{-1}$ of the soil C present in 1947 was derived from these residues and results in an efficiency of incorporation of $4.7 \%$ in the top $30 \mathrm{~cm}$. Additional $\mathrm{C}_{3}$ plant $\mathrm{C}$ was probably incorporated at greater depth, but we had no soil samples from 1947 archived from those depths. The corresponding efficiency of incorporation between 1947 to 1993 was calculated as $5.6 \%$. A total of $99100 \mathrm{~kg} \mathrm{ha}^{-1}$ of plant residues was returned to the soil from 1909 to 1993 . About 5400 $\mathrm{kg} \mathrm{ha}^{-1}$ of the soil C present in 1993 was derived from these residues and results in an efficiency of incorporation of $5.4 \%$ into the top $30 \mathrm{~cm}$ of soil during the entire $84 \mathrm{yr}$ of cultivation.

Because some of the data available was meager and because of the assumptions required, there is uncertainty in the accuracy of the estimated crop residue inputs. In addition, there is considerable variation among researchers for calculating efficiencies. The method we used to calculate efficiency of incorporation was based on changes in the ${ }^{13} \mathrm{C} /{ }^{12} \mathrm{C}$ isotopic ratios (Eq. 


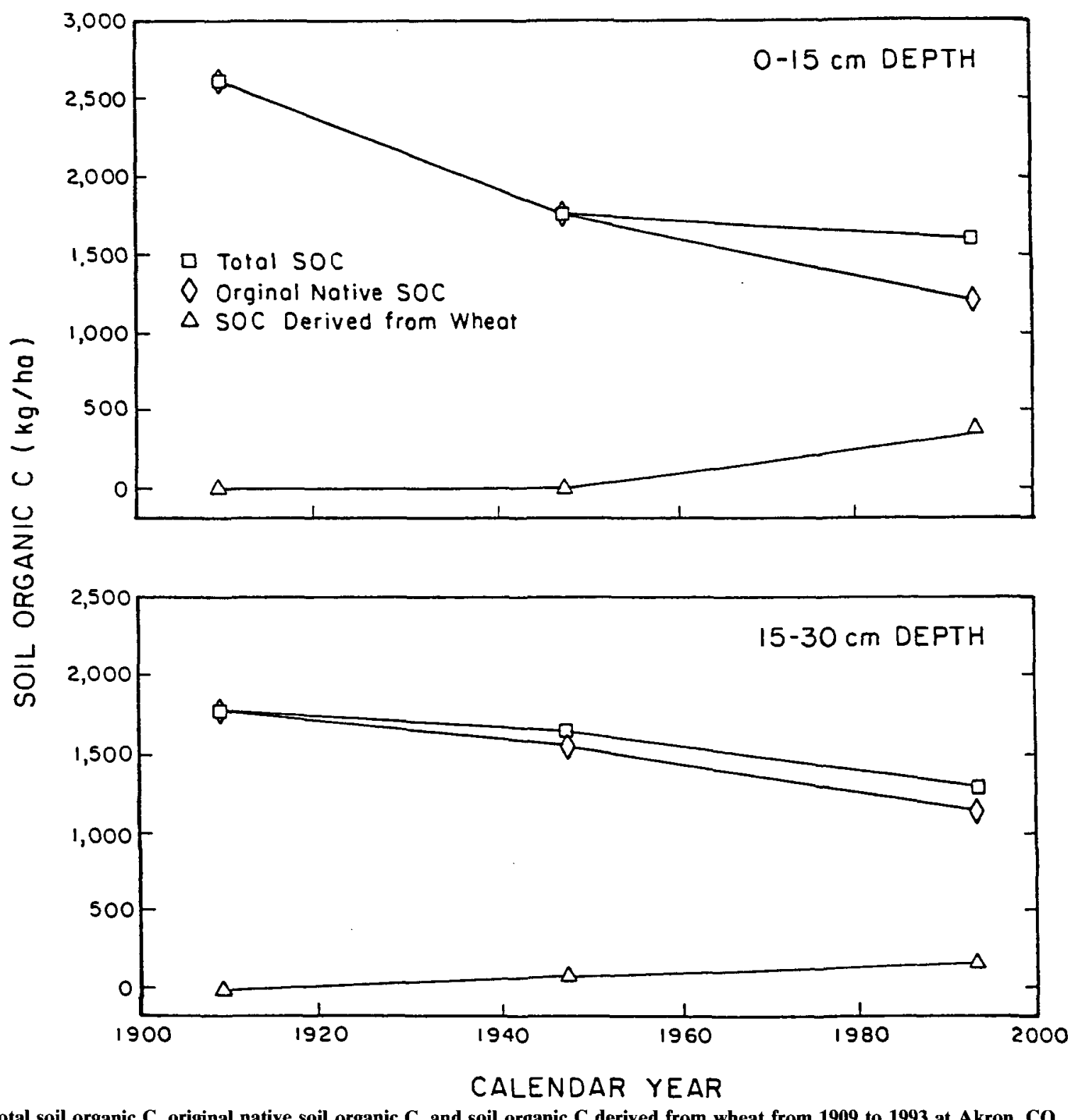

Fig. 2. Total soil organic $C$, original native soil organic $C$, and soil organic $C$ derived from wheat from 1909 to 1993 at $A k r o n$, CO.

[2]). Woomer et al. (1997) defined efficiency of C sequestration as proportion of $\mathrm{C}$ inputs that result in changes in SOC expressed as a percentage. Woomer et al. (1997) observed efficiencies ranging from 1.4 to $6.9 \%$ in Kenya, Africa, for a stover return plus annual fertilizer $\left(120 \mathrm{~kg} \mathrm{~N} \mathrm{ha}^{-1}\right.$ and $\left.54 \mathrm{~kg} \mathrm{P} \mathrm{ha}^{-1}\right)$ treatment and a fertilizer plus annual manure $\left(10 \mathrm{Mg} \mathrm{ha}^{-1}\right)$ treatment, respectively. Rasmussen and Albrecht (1997) in Pendleton, OR, report that about $18 \%$ of all residues are incorporated into SOC, but that the $\mathrm{C}$ input necessary to maintain SOC in soil at equilibrium appears to increase with increasing precipitation. Parton and Rasmussen (1994), for Pendleton, OR, used the CENTURY computer model to report a $\mathrm{C}$ stabilization efficiency of from 12 to $27 \%$. They defined $\mathrm{C}$ stabilization efficiency as the change in SOC compared with change in a control treatment (no N additions). Finally, Uhlen (1991) reported that residual $\mathrm{C}$ is about $7 \%$ of the $\mathrm{C}$ addition in straw applied annually for $31 \mathrm{yr}$ on a clay loam soil in Norway.

\section{Akron, Colorado - Soil Carbon with Depth}

The SOC decreased with depth for both the native and cultivated sites at Akron (Table 2). The $\delta^{13} \mathrm{C}$ of the native site was less negative with depth and was consistent with our observations for other sites throughout the Great Plains. The $\delta^{13} \mathrm{C}$ for cultivated soil was $3.2 \%$ more negative in the surface $(0-10-\mathrm{cm}$ depth) than was the native soil. Effect of wheat on $\delta^{13} \mathrm{C}$ decreased with depth, being only $1.2 \%$ more negative for the cultivated soil than for the native soil at the $20-$ to $30-\mathrm{cm}$ depth. We do not understand the $\delta^{13} \mathrm{C}$ anomaly at 60 to $90-\mathrm{cm}$ at the cultivated site, but it may result from a different parent material in this deep and probably very old layer. 
Table 3. Plant $\mathrm{C}$ inputs into the Akron, CO, and Sidney, NE, wheat-fallow sites. $\dagger$

\begin{tabular}{|c|c|c|c|c|c|c|}
\hline Years & $\begin{array}{l}\text { Cumulative } \\
\text { grain yield }\end{array}$ & $\begin{array}{c}\begin{array}{c}\text { Straw C } \\
\text { inputs }\end{array} \\
\end{array}$ & $\begin{array}{c}\text { Root C } \\
\text { inputs }\end{array}$ & $\begin{array}{c}\text { Weed C } \\
\text { inputs }\end{array}$ & $\begin{array}{l}\text { Total C } \\
\text { inputs }\end{array}$ & $\begin{array}{c}\text { Annual } \\
\text { inputs }\end{array}$ \\
\hline & $\mathbf{k g ~ h a}^{-1}$ & 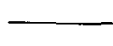 & 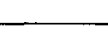 & kg C ha ${ }^{-1}$ & 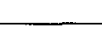 & 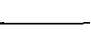 \\
\hline \multicolumn{7}{|c|}{ Akron, Co } \\
\hline $\begin{array}{l}1909-1916 \\
1917-1930 \\
1931-1947 \\
1948-1960 \\
1961-1975 \\
1976-1993\end{array}$ & $\begin{array}{r}4520 \\
3800 \\
7560 \\
11200 \\
16230 \\
25080\end{array}$ & $\begin{array}{r}1010 \\
850 \\
1700 \\
7620 \\
11040 \\
17050\end{array}$ & $\begin{array}{r}2580 \\
2170 \\
4310 \\
6380 \\
9250 \\
14300\end{array}$ & $\begin{array}{l}1260 \\
1060 \\
2100 \\
3500 \\
5070 \\
7840\end{array}$ & $\begin{array}{r}4850 \\
4080 \\
8110 \\
17500 \\
25360 \\
39190\end{array}$ & $\begin{array}{r}610 \\
290 \\
480 \\
1350 \\
1690 \\
2180\end{array}$ \\
\hline $\begin{array}{l}1909-1947 \\
1948-1993\end{array}$ & $\begin{array}{l}15880 \\
52510\end{array}$ & $\begin{array}{r}3560 \\
35710\end{array}$ & $\begin{array}{r}9050 \\
29930\end{array}$ & $\begin{array}{r}4420 \\
16410\end{array}$ & $\begin{array}{l}17030 \\
82050\end{array}$ & $\begin{array}{r}440 \\
1780\end{array}$ \\
\hline \multicolumn{7}{|c|}{ Sidney, NE } \\
\hline $1973-1993$ & 24910 & 18180 & 14200 & 8100 & 40480 & 2020 \\
\hline
\end{tabular}

$\dagger$ The assumptions for these calculations are: (i) straw to grain ratio was 1.7 at Akron, CO; (ii) straw to grain ratio was 1.8 at Sidney, NE; (iii) straw is $40 \% \mathrm{C}$ and roots are $38 \% \mathrm{C}$; (iv) root $\mathrm{C}=$ grain weight times 0.57 ; (v) estimated weed $\mathrm{C}$ input equaled 0.35 times straw $\mathrm{C}$ plus root $\mathrm{C}$ inputs from 1909 to 1947; (vi) estimated weed $C$ input equaled 0.25 times straw $C$ plus root $C$ inputs from 1948 to 1993 ; (vii) only one-third of the straw was returned to the field through 1947, but all of the straw was returned after 1947.

As reported by Paul et al. (1997), there is an increase in SOC age of from $193 \mathrm{yr}$ in the 0 - to $10-\mathrm{cm}$ depth to $>4000 \mathrm{yr}$ in the 30 - to $45-\mathrm{cm}$ depth. The ${ }^{14} \mathrm{C}$ age of the nonhydrolyzable fraction is much older and increased in age from about $2000 \mathrm{yr}$ in the $0-$ to $10-\mathrm{cm}$ depth to about $7600 \mathrm{yr}$ in the $30-$ to $45-\mathrm{cm}$ depth. Our data show the nonhydrolyzable $\mathrm{C}$ in the native soil decreased nearly $17 \%$ from the 0 - to 10 - to the 30 - to $60-\mathrm{cm}$ depth while that for the cultivated site decreased nearly $9 \%$ (Table 2). The percentage of nonhydrolyzable $\mathrm{C}$ of the cultivated site was inconsistent at the $90-$ to $120-\mathrm{cm}$ depth. We observed that $\delta^{13} \mathrm{C}$ of the nonhydrolyzable fraction in the native soil became more negative with depth rather than less negative, as had been observed for total SOC. Thus, $\delta^{13} \mathrm{C}$ of nonhydrolyzable soil C went from 3.0\% more negative than the SOC in the 0 to $10-\mathrm{cm}$ depth to $7.7 \%$ more negative in the 30 - to 60 $\mathrm{cm}$ depth. These differences between $\delta^{13} \mathrm{C}$ for the SOC and that of the nonhydrolyzable $\mathrm{C}$ was similar with depth for the cultivated soil, but differences were smaller (Table 2). Trends for age of soil and nonhydrolyzable C with depth (Paul et al., 1997) for the cultivated site paralleled that from the native site. Based on our data (Table 2) and those of Paul et al. (1997), one would like to correlate that age of nonhydrolyzable $\mathrm{C}$ shows resistance of the nonhydrolyzable fraction to decomposition. However, the decrease in its amount with soil depth requires caution. Our observations for nonhydrolyzable $\mathrm{C}$, compared with SOC, probably requires additional research to explain its importance.

The $\mathrm{C}$ concentration and $\delta^{13} \mathrm{C}$ of wheat straw and corn stover and their nonhydrolyzable $\mathrm{C}$ and its $\delta^{13} \mathrm{C}$ are shown in Table 2. Difference in $\delta^{13} \mathrm{C}$ of total plant and nonhydrolyzable plant $\mathrm{C}$ is similar to that of SOC and nonhydrolyzable surface-soil $\mathrm{C}$. However, the difference in $\delta^{13} \mathrm{C}$ of nonhydolyzable $\mathrm{C}$ compared with SOC became much more negative with soil depth.

\section{Sidney, Nebraska (1972-1993)}

The site was in native grass until 1970 when moldboard plowed and placed into alternate winter wheatfallow. Original surface-soil $\mathrm{pH}$ in the 0 - to 10 - and 10 - to 20-cm depths was 7.4; SOC was 23.3 and $15.5 \mathrm{~g} \mathrm{~kg}^{-1}$ (Fenster and Peterson, 1979) for these same depths, respectively. Concentration of SOC and $\delta^{13} \mathrm{C}$ were measured in soil samples collected from replicated plots in 1993 (Table 4). The SOC concentrations of the native and sod treatments were higher in surface soil layers than for the plow treatment. As described above, 1993 "native" soil samples were collected from an adjacent grazed native prairie. Sod and plow treatments had a more negative $\delta^{13} \mathrm{C}$ in the topsoil layers than native soil samples. Average $\delta^{13} \mathrm{C}$ for native soil samples were more negative than for sod and plow treatments at depths below $60 \mathrm{~cm}$.

Soil samples archived in 1972 from the plow treatment were compared with those collected in 1993. Use of archived samples to compare with those collected from the same replicated plots in 1993 should be the best reference for changes that have occurred in $\delta^{13} \mathrm{C}$ and SOC. In $1972, \delta^{13} \mathrm{C}$ values were $-19.29 \pm 0.13 \%$ (0-10$\mathrm{cm}$ depth) and $-18.31 \pm 0.44 \%$ (10-20-cm depth); SOC averaged $22.1 \pm 1.0$ and $12.2 \pm 0.5 \mathrm{~g} \mathrm{~kg}^{-1}$ for these same two depths. The $\delta^{13} \mathrm{C}$ values of 1993 soil samples from the plow treatment were $-19.76 \pm 0.26 \%$ o $(0-10$ cm depth) and $-19.69 \pm 0.40 \%$ (10-20-cm depth); SOC was $13.5 \pm 1.0 \mathrm{~g} \mathrm{~kg}^{-1}(0-10-\mathrm{cm}$ depth $)$ and $13.9 \pm 1.4$ $\mathrm{g} \mathrm{kg}^{-1}$ (10-20-cm depth) (Table 4). Because no data were available, we assumed that bulk densities of 1972 samples were the same as those measured in 1993:1.22 \pm $0.08\left(0-10-\mathrm{cm}\right.$ depth) and $1.36 \pm 0.10 \mathrm{~g} \mathrm{~cm}^{-3}(10-20-$ cm depth).

Computations (Eq. [2]) were similar to those for

Table 4. Soil organic $C$ and $\delta^{13} \mathrm{C}$ with profile depth for 1993 samples collected from plots at Sidney, NE.

\begin{tabular}{|c|c|c|c|c|c|c|}
\hline \multirow[b]{2}{*}{ Depth } & \multicolumn{3}{|c|}{ Soil organic $\mathbf{C}$} & \multicolumn{3}{|c|}{$\delta^{13} \mathrm{C}$} \\
\hline & Native & Sod & Plow & Native & Sod & Plow \\
\hline cm & 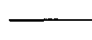 & $\mathbf{k g}^{-1}$ & 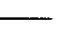 & & $-\%$ & \\
\hline 0-10 & 18.9 & 32.6 & 13.5 & -16.4 & -20.1 & -19.8 \\
\hline $10-20$ & 13.6 & 15.7 & 13.9 & -15.6 & -18.7 & -19.7 \\
\hline $20-30$ & 9.3 & 10.2 & 9.0 & -15.9 & -17.7 & -18.1 \\
\hline $30-60$ & 6.9 & 7.3 & 6.9 & -17.2 & -17.5 & $-\mathbf{1 7 . 3}$ \\
\hline $60-90$ & 5.8 & 5.7 & 5.3 & -18.5 & -17.4 & -17.4 \\
\hline $90-120$ & 4.5 & 4.6 & 4.5 & -18.5 & -17.7 & -17.9 \\
\hline
\end{tabular}


Akron and show that, by 1993, original native SOC dropped to $61 \%$ of the 1972 level in the $0-$ to $10-\mathrm{cm}$ depth, but increased to $113 \%$ in the 10 - to 20 -cm layer. The observed SOC increase in the 10- to $20-\mathrm{cm}$ depth was probably the result of mixing of SOC from the 0to $10-\mathrm{cm}$ depth into the $10-$ to $20-\mathrm{cm}$ depth by plowing. By 1993, SOC in the 0 - to $20-\mathrm{cm}$ depth was $81 \%$ of that observed in 1972. Amounts of SOC in 1993 are in Table 5. By 1993 , soil C derived from $\mathrm{C}_{3}$ plant residues (wheat) was about $7 \%$ of the SOC present in the $0-$ to $10-\mathrm{cm}$ depth and about $17 \%$ of that present in the 10 - to 20 cm depth; these amounts represent 1080 and $3190 \mathrm{~kg} \mathrm{C}$ $\mathrm{ha}^{-1}$, respectively, for these two depths. For the top 20 $\mathrm{cm}$, average annual rate of SOC loss was about $420 \mathrm{~kg}$ $\mathrm{C} \mathrm{ha}^{-1}$ from 1972 to 1993. Rate of average annual addition of SOC derived from $\mathrm{C}_{3}$ plants to the top $20 \mathrm{~cm}$ of soil was about $210 \mathrm{~kg} \mathrm{C} \mathrm{ha}^{-1}$.

For the sod treatment, we used the measurement of $\delta^{13} \mathrm{C}$ in 1993 aboveground plant "grab" samples to estimate relative amounts of $\mathrm{C}_{3}$ vs. $\mathrm{C}_{4}$ plant biomass; $\delta^{13} \mathrm{C}$ for these samples averaged $-25.74 \pm 0.49 \%$. Using the mixing equation describe above (Table 1), grab samples contained about $98 \% \mathrm{C}_{3}$ vegetation. For grazed native pasture, we visually observed mostly native $\mathrm{C}_{4}$ grasses, such as blue grama (Boutaloua gracilis Willd. ex Kunth). This observation is supported by $\delta^{13} \mathrm{C}$ signatures of the SOC from the native pasture surrounding the plots, indicating that historically there was about $70 \% \mathrm{C}_{4}$ vegetation (Table 1). Probably, the lack of grazing (or fire) on the sod treatment between 1972 and 1993 has resulted in increased overwinter vegetative height and additional snow trapping, increased available spring soil moisture, increased plant-residue accumulation and possibly production, a vegetative shift to $\mathrm{C}_{3}$ grasses, and increased SOC. Additional evidence of a shift to $\mathrm{C}_{3}$ vegetation in the sod plots is provided by analyses of SOC for samples collected in 1972 and 1993. Average $\delta^{13} \mathrm{C}$ for 1972 soil samples from the sod plots were $-18.88 \pm 0.28$ and $-17.82 \pm 0.28 \%$ in the 0 - to 10 - and 10- to $20-\mathrm{cm}$ depths, respectively; corresponding values for these two depths in 1993 were $-20.14 \pm 0.44$ and $-18.71 \pm 0.28 \%$. Therefore, soil analyses for $\delta^{13} \mathrm{C}$ provide strong evidence of a shift to $\mathrm{C}_{3}$ vegetation. Thus, we did not use the sod treatment as a reference for this study (Table 4).

Sidney had lower annual-crop yields than did Akron. Straw to grain ratio at Sidney was 1.8 vs. 1.7 at Akron. Straw, root, and weed C inputs were calculated for replicated plots of the plow treatment (Table 3). They totaled about $40480 \mathrm{~kg} \mathrm{C} \mathrm{ha}^{-1}$. Stable isotope calculation (Eq.

Table 5. Weight of total organic $\mathrm{C}$ with depth at the Akron, $\mathrm{CO}$, and Sidney, NE, sites in 1993.

\begin{tabular}{|c|c|c|c|c|c|}
\hline \multirow[b]{2}{*}{ Depth } & \multicolumn{2}{|c|}{ Akron, CO } & \multicolumn{3}{|c|}{ Sidney, NE } \\
\hline & Native & Plow & Sod & Native & Plow \\
\hline cm & & - & $\left(\mathrm{ha}^{-1}\right) / \mathrm{c}$ & & \\
\hline $\begin{array}{l}0-10 \\
10-20 \\
20-30 \\
30-60\end{array}$ & $\begin{array}{l}18433 \\
13490 \\
12017 \\
21326\end{array}$ & $\begin{array}{r}10583 \\
9919 \\
7730 \\
26420\end{array}$ & $\begin{array}{r}24988 \\
18076 \\
12837 \\
9050\end{array}$ & $\begin{array}{r}20373 \\
17280 \\
12638 \\
8841\end{array}$ & $\begin{array}{r}1651 \\
1881 \\
1132 \\
855\end{array}$ \\
\hline Total & 65267 & 54653 & 64952 & 59131 & 5521 : \\
\hline
\end{tabular}

[2]) and measurement of $\delta^{13} \mathrm{C}$ from 1972 and 1993 samples show that about $4270 \mathrm{~kg}$ of the $35330 \mathrm{~kg}$ of SOC $\mathrm{ha}^{-1}$ remaining in the top $20 \mathrm{~cm}$ of the plowed soil at Sidney in 1993 (Table 5) resulted from C inputs by $\mathrm{C}_{3}$ plants. During that time, cultivation had decreased SOC in the top 20-cm depth from 43640 to $35330 \mathrm{~kg} \mathrm{ha}^{-1}$, a net long-term rate of $C$ loss of about $420 \mathrm{~kg} \mathrm{C} \mathrm{ha}^{-1}$ $\mathrm{yr}^{-1}$. Calculated SOC accretion from $\mathrm{C}_{3}$ plants was about $210 \mathrm{~kg} \mathrm{C} \mathrm{ha}^{-1} \mathrm{yr}^{-1}$. Therefore, gross annual $\mathrm{C}$ loss was about $630 \mathrm{~kg}$ of original native SOC. Total calculated input of plant $C$ was $40500 \mathrm{~kg} \mathrm{ha}^{-1}$ (Table 3) and stable isotope calculations are that about $4270 \mathrm{~kg} \mathrm{C} \mathrm{ha}^{-1}$ from $\mathrm{C}_{3}$ plants was present in 1993. Thus, plant-residue C storage efficiency at Sidney is about $10.5 \%$ in the top $20 \mathrm{~cm}$ of soil.

\section{Soil Organic Carbon Accretion (Akron, Colorado, and Sidney, Nebraska)}

As reported above for long-term plots at Akron, about 21 and $18 \mathrm{~kg}$ of plant-residue $\mathrm{C}$ were required for each kilogram of $C$ sequestered into the SOC pool from 1909 to 1947 and 1948 to 1993, respectively. Comparable calculations for long-term plots at Sidney are $10 \mathrm{~kg}$ of plant- residue $\mathrm{C}$ for each kilogram of $\mathrm{C}$ sequestered from 1972 to 1993. Soil texture does not explain the larger amount of residues required per unit of sequestered SOC at Akron than Sidney. Surface-soil (0-15-cm depth) sand, silt, and clay contents for both sites were between 34 to 40,34 to 39 , and 25 to $28 \%$, respectively; $\mathrm{pH}$ was between 6.8 and 7.0. Average SOC contents $(0-10-\mathrm{cm}$ depth) for cultivated plots at Akron and Sidney in 1993 were 8.8 and $13.5 \mathrm{~g} \mathrm{C} \mathrm{kg}^{-1}$, respectively. Average SOC for native prairie soils $(0-10-\mathrm{cm}$ depth) were 14.7 and $18.9 \mathrm{~g} \mathrm{C} \mathrm{kg}^{-1}$, respectively (Tables 2 and 4). Lower SOC in the cultivated plots at Akron results from much longer cultivation than at Sidney. However, the difference in SOC of native prairie sites probably reflects inherent differences between these soils in their SOC accretion potentials. Soil from the Sydney plow treatment in 1972 contained $17.2 \mathrm{~g} \mathrm{C} \mathrm{kg}^{-1}$, and also indicates a higher SOC accretion potential.

\section{Soil Organic Carbon Depletion with Depth (Akron, Colorado, and Sidney, Nebraska)}

Data collected in 1993 included SOC content and $\delta^{13} \mathrm{C}$ with depth at Akron and Sidney. Large changes were observed in the sod treatment at Sidney from 1970 and 1993. Total SOC concentrations $\left(\right.$ SOC $\left._{C}\right)$ were measured for sod and plow treatments in 1970 (Fenster and Peterson, 1979), in 1986 (Follett and Peterson, 1988), and in archived samples from 1972 and 1982 but analyzed with 1993 samples. Soil bulk density was unavailable for samples before 1993; thus concentration, not weight, of SOC is reported. Regression of $\mathrm{SOC}_{C}$ against years of cultivation since $1970(0-10-\mathrm{cm}$ depth) resulted in equations with positive slope for the sod treatment $\left(\mathrm{SOC}_{\mathrm{C}}=0.4 y+22.5, r^{2}=0.72\right)$, but negative slope for the plow treatment $\left(\mathrm{SOC}_{\mathrm{C}}=-0.4 y+22.7, r^{2}=0.89\right)$. Data regression for the 10 - to $20-\mathrm{cm}$ depth resulted in equations with positive slopes for both sod $\left(\mathrm{SOC}_{C}=\right.$ 
$\left.0.2 y+11.9, r^{2}=0.53\right)$ and plow $\left(\mathrm{SOC}_{\mathrm{C}}=0.1 y+12.6\right.$, $\left.r^{2}=0.26\right)$ treatments. We doubted that the sod treatment represented a native prairie condition, so SOC in the plow treatment in 1993 was compared with SOC from three replications of the grazed native pasture (outside the fence surrounding the other plots) (Table 5).

We observed larger amounts of SOC below $30 \mathrm{~cm}$ at Akron than at Sidney for all treatments. Important may be a relationship of years of cultivation to depth of SOC depletion when compared with native prairie (Table 5). At Akron, soil had been cultivated for $84 \mathrm{yr}$ and SOC depleted to the $30-\mathrm{cm}$ depth compared with the native site. At Sidney the soil had been cultivated for $22 \mathrm{yr}$ and SOC depleted (within 1 standard deviation) to 10 $\mathrm{cm}$. This observation indicates that continuous cultivation initially depletes near-surface soil-C stocks and, with increasing time of cultivation, deeper soil-C stocks are depleted.

\section{SUMMARY AND CONCLUSIONS}

Use of stable $\mathrm{C}$ isotopes to assess cultivation effects is greatly helped if the $\delta^{13} \mathrm{C}$ in SOC resulted from vegetation whose $\delta^{13} \mathrm{C}$ is quite different from that of the crop that is subsequently grown and if the onset time of vegetative change is known (Balesdent et al., 1987; van Kessel et al., 1994). Our data show that the $\delta^{13} \mathrm{C}$ in the SOC in native grassland surface and subsurface soils from the Great Plains in North America becomes less negative from north to south as the result of a broad regional shift from predominantly $\mathrm{C}_{3}$ to $\mathrm{C}_{4}$ vegetation. In addition, historical vegetation changes and possible climate change effects may have occurred. Fairly recent historical vegetation increases in shrubby $\mathrm{C}_{3}$ species may help explain more negative $\delta^{13} \mathrm{C}$ trends in surface and subsurface soils near Lawton, OK, and Big Springs, TX. Regional patterns of $\delta^{13} \mathrm{C}$ in the Great Plains show consistent trends of more negative $\delta^{13} \mathrm{C}$ in younger surface soils than in older subsurface soils (based on ${ }^{14} \mathrm{C}$ dating); this may indicate a shift from $\mathrm{C}_{4}$ to more $\mathrm{C}_{3}$ plant residue inputs during the past few hundreds to thousands of years and be related to a somewhat cooler (or wetter) climate at present than in the past.

Introduction of various $\mathrm{C}_{3}$ or $\mathrm{C}_{4}$ crop $\mathrm{C}$ residue inputs and cropping systems into the Great Plains is now superimposed on historical $\delta^{13} \mathrm{C}$ patterns in SOC and it is now important to understand how losses of original prairie $\mathrm{SOC}$ and sequestration of residue $\mathrm{C}$ derived from crops in this important agricultural region may influence net $\mathrm{CO}_{2}$ exchange with the atmosphere, global change, or other major agricultural issues. The 1993 soil sampling of two long-term field experiments near Akron, CO, and Sidney, NE, allow stable $\mathrm{C}$ isotope analyses for estimating efficiency of incorporation of small-grain crop residue $\mathrm{C}$ into the SOC. The long-term plot area near Akron has been cultivated since 1909; also available were archived soil samples from 1947 and longterm yield records. The long-term plot area near Sidney has been cultivated since 1970; available from Sidney were archived soil samples from 1972 and 1982 and yield records.

For Akron, our calculations indicate that by 1947,
SOC had decreased to $68 \%$ of its original (1909) level in the 0 - to $15-\mathrm{cm}$ depth and to $92 \%$ in the 15 - to $30-$ cm depth; by 1993, SOC for these same two depths had decreased to 61 and $72 \%$. By 1993, based on $\delta^{13} \mathrm{C}$ analyses, prairie-vegetation-derived SOC had decreased to only $46 \%$ of its original level in the 0 - to $15-\mathrm{cm}$ depth and $63 \%$ in the $15-$ to $30-\mathrm{cm}$ depth. A small amount of $\mathrm{C}_{3}$ plant $\mathrm{C}$ (from winter wheat) was sequestered into the SOC pool by 1947 ; however, by 1993 about $24 \%$ of the SOC in the 0- to $15-\mathrm{cm}$ depth and $12 \%$ of the SOC in the 15- to $30-\mathrm{cm}$ depth was derived from $\mathrm{C}_{3}$ plants. Average annual rate of SOC addition of $\mathrm{C}_{3}$-derived plant $\mathrm{C}$ to the 0 - to $30-\mathrm{cm}$ depth increased from about 20 to about $180 \mathrm{~kg} \mathrm{C} \mathrm{ha}^{-1}$ between the periods of 1909 to 1947 and 1947 to 1993 . Even though there is now a decreased rate of loss of SOC from these soils and increased rates of $\mathrm{C}_{3}$-plant-derived SOC being returned, continued loss of the original prairie-vegetation-derived SOC to at least the $30-\mathrm{cm}$ depth and the dynamics of this loss are not understood.

For Sidney, our calculations indicate that from 1972 to 1993 , original prairie-vegetation-derived SOC decreased to $61 \%$ in the 0 - to $10-\mathrm{cm}$ depth, but increased to $113 \%$ in the $10-$ to $20-\mathrm{cm}$ depth. The increase in the $10-$ to $20-\mathrm{cm}$ depth was attributed to a redistribution of the soil surface SOC to the deeper depth by plowing. Soil $\mathrm{C}$ derived from $\mathrm{C}_{3}$ plant residues (wheat) was about $7 \%$ of the SOC present in the $0-$ to $10-\mathrm{cm}$ depth and $17 \%$ in the $10-$ to $20-\mathrm{cm}$ depth. For the top $20 \mathrm{~cm}$, average annual rate of SOC loss was about $420 \mathrm{~kg} \mathrm{C} \mathrm{ha}^{-1}$ from 1972 to 1993 . The corresponding rate of addition of $\mathrm{C}_{3}$-plant-derived $\mathrm{C}$ was about $210 \mathrm{~kg} \mathrm{ha}^{-1}$. Comparison of Akron and Sidney data indicate that continuous cultivation initially depletes near-surface soil-C stocks and with increasing time, deeper soil-C stocks are depleted. These observations have important implications about effects of cultivation and crop production and especially the role of soil as a reservoir for sequestering atmospheric $\mathrm{CO}_{2}-\mathrm{C}$, a greenhouse gas.

\section{ACKNOWLEDGMENTS}

The authors gratefully acknowledge the contributions of E.G. Pruessner for sample preparation and the many analytical determinations that she made and to A.L. Black and F. Jacober for assisting us in locating archived soil samples from many of the locations that were analyzed and are reported from the Great Plains of the USA. Special appreciation is given to Dr. L.K. Porter and E.D. Buenger for their assistance and expertise with the analytical equipment that was used. Appreciation is also expressed to K. DeWitte, D. Kane, and B. McCaleb for their help in preparing and analyzing standards with IRMS.

\section{REFERENCES}

Balesdent, J., A. Mariotti, and B. Guillet. 1987. Natural ${ }^{13} \mathrm{C}$ abundance as a tracer for studies of soil organic matter dynamics. Soil Biol. Biochem. 19:25-30.

Balesdent, J., G.H. Wagner, and A. Mariotti. 1988. Soil organic matter turnover in long-term field experiments as revealed by carbon-13 natural abundance. Soil Sci. Soc. Am. J. 52:118-124.

Balesdent, J., and M. Balabane. 1992. Maize root-derived SOC estimated by natural ${ }^{13} \mathrm{C}$ abundance in maize fields. Soil Biol. Biochem. 24:97-101.

Barrie, A., S. Debney, C.T. Workman, and C. Pullan. 1995. Recent 
developments in high productivity stable isotope analysis. p. 29-61. In Proc. Int. Symp. nuclear and related techniques in soil-plant studies on sustainable agriculture and environmental preservation. 17-21 Oct. 1994. IAEA, Vienna.

Boutton, T.W. 1991. Stable carbon isotope ratios of natural materials: I. Sample preparation and Mass spectrometric analysis. p. 155-171. In D.C. Coleman and B. Fry (ed.) Carbon isotope techniques. Academic Press, New York.

Brandon, J.F., and O.R. Mathews. 1944. Dry land rotation and tillage experiments at the Akron (Colorado) Field Station. USDA Circ. 700. U.S. Gov. Print. Office, Washington, DC.

Buyanovsky, G.A., C.L. Kucera, and G.H. Wagner. 1987. Comparative analyses of carbon dynamics in native and cultivated ecosystems. Ecology 68:2023-2031.

Buyanovsky, G.A., and G.H. Wagner. 1986. Post-harvest residue input into cropland. Plant Soil 93:57-65.

Buyanovsky, G.A., and G.H. Wagner. 1987. Carbon transfer in a winter wheat (Triticum aestivum) ecosystem. Biol. Fertil. Soils 5:76-82.

Buyanovsky, G.A., and G.H. Wagner. 1995. Soil respiration and carbon dynamics in parallel native and cultivated ecosystems. p. 209217. In R. Lal et al. (ed.) Soils and global change. CRC Lewis Publ., Boca Raton, FL.

Fenster, C.R., and G.A. Peterson. 1979. Effects of no-tillage fallow as compared to conventional tillage in a wheat-fallow system. Bull. 289. Nebraska Agric. Exp. Stn., Lincoln.

Flint, R.F. 1947. Glacial geology and the Pleistocene epoch. John Wiley \& Sons, NewYork.

Flint, R.F. 1967. Glacial and Pleistocene geology. John Wiley \& Sons, New York.

Follett, R.F., and G.A. Peterson. 1988. Surface soil nutrient distribution as affected by wheat-fallow tillage systems. Soil Sci. Soc. Am. J. 52:141-147.

Greb, B.W. 1983. Water conservation: Central Great Plains. p. 57-72. In H.E. Dregne and W.O. Willis (ed.) Dryland agriculture. Agron. Monogr. 23. ASA, CSSA, and SSSA, Madison, WI.

Gregorich, E.G., B.H. Ellert, C.F. Drury, and B.C. Liang. 1996. Fertilization effects on soil organic matter turnover and corn residue $\mathrm{C}$ storage. Soil Sci. Soc. Am. J. 60:472-476.

Gregorich, E.G., B.H. Ellert, and C.M. Monreal. 1995a. Storage of soil carbon in the light fraction and macroorganic matter. p. 167-190. In M.R. Carter and B.A. Stewart (ed.) Structure and soil organic matter storage in agricultural soils. Lewis Publ., Boca Raton, FL.

Gregorich, E.G., B.H. Ellert, and C.M. Monreal. 1995b. Turnover of soil organic matter and storage of corn residue carbon estimated from natural ${ }^{13} \mathrm{C}$ abundance. Can. J. Soil Sci. 75:161-167.

Haas, H.J., C.E. Evans, and E.F. Miles. 1957. Nitrogen and carbon changes in Great Plains soils as influenced by cropping and soil treatments. USDA Tech. Bull. 1164. U.S. Gov. Print. Office, Washington, $\mathrm{DC}$.

Hsieh, Y.P. 1996. Soil organic carbon pools of two tropical soils inferred by carbon signatures. Soil Sci. Soc. Am. J. 60:1117-1121.

Jenny, H. 1941. Factors of soil formation. McGraw-Hill, New York.

Kelly, E.F., C. Yonker, and B. Marino. 1993. Stable carbon isotope composition of paleosols: An application to Holocene. Geophys. Monogr. Am. Geophys. Union 78:233-239.

Kurmann, M.H. 1985. An opal phytolith and palynomorph study of extant and fossil soils in Kansas (U.S.A.). Palaeogeogr. Palaeoclimatol. Palaeoecol. 49:217-235.

Leuenberger, M., U. Siegenthaler, and C.C. Langway. 1992. Carbon isotope composition of atmospheric $\mathrm{CO}_{2}$ during the last ice age from an antarctic ice core. Nature (London) 357:488-490.

Marino, B.D., and M.B. McElroy. 1991. Isotopic composition of atmospheric carbon in $\mathrm{C}_{4}$ plant leaves. Nature (London) 349:127-131.

Marino, B.D., M.B. McElroy, R.J. Salawitch, and W.G. Spaulding. 1992. Glacial-to-interglacial variations in the carbon isotopic composition of atmospheric $\mathrm{CO}_{2}$. Nature (London) 357:461-465.

Martel, Y.A. 1972. The use of radiocarbon dating for investigating the dynamics of soil organic matter. Ph.D. diss. Univ, of Saskatchewan, Saskatoon.

Martel, Y.A., and E.A. Paul. 1974. Effects of cultivation on the organic matter of grassland soils as determined by fractionation and radiocarbon dating. Can. J. Soil Sci. 54:419-426.

Martin, A., A. Mariotti, J. Balesdent, P. Lavelle, and R. Vuattoux. 1990. Estimate of organic matter turnover rate in a savanna soil by ${ }^{13} \mathrm{C}$ natural abundance measurements. Soil Biol. Biochem. 22:517-523.

Mary, B., A. Mariotti, and J.L. Morel. 1992. Use of ${ }^{13} \mathrm{C}$ variations at natural abundance for studying the biodegradation of root mucilage, roots, and glucose in soil. Soil Biol. Biochem. 24:1065-1077.

Parr, J.F., and R.I. Papendick. 1978. Factors affecting the decomposition of crop residues by microorganisms. p. 101-129. In W.R. Oschwald (ed.) Crop residue management systems. ASA Spec. Publ. 31. ASA, CSSA, and SSSA, Madison, WI.

Parton, W.J., and P.E. Rasmussen. 1994. Long-term effects of crop management in wheat-fallow: II. CENTURY model simulations. Soil Sci. Soc. Am. J. 58:530-536.

Paul, E.A., R.F. Follett, S.W. Leavitt, A. Halvorson, G. Peterson, and D. Lyon. 1997. Radiocarbon dating for determination of soil organic matter pool sizes and dynamics. Soil Sci. Soc. Am. J. 61: $1058-1067$ (this issue).

Rasmussen, P.E., and S.L. Albrecht. 1997. Crop management effects on organic carbon in semi-arid Pacific Northwest soils. In R.Lal et al. (ed.) Soil processes and the carbon cycle. Adv. Soil Sci. CRC Press, Boca Raton, FL (in press).

Swinnen, J., J.A. Van Veen, and R. Merckx. 1995. Root decay and turnover of rhizodeposits in field-grown winter wheat and spring barley estimated by ${ }^{14} \mathrm{C}$ pulse-labeling. Soil Biol. Biochem. 27:211-217.

Soil Survey Staff. 1994. Keys to soil taxonomy. 6th ed. U.S. Gov. Print. Office, Washington, DC.

Toolin, L.J., and C.J. Eastoe. 1993. Late Pleistocene-recent atmospheric $\delta^{13} \mathrm{C}$ record in $\mathrm{C}_{4}$ grasses. Radiocarbon 35:263-269.

Uhlen, G. 1991. Long-term effects of fertilizers, manure, straw and crop rotation on total- $\mathrm{N}$ and total- $\mathrm{C}$ in soil. Acta Agric. Scand. 41:119-127.

U.S. Department of Agriculture. 1978. Improving soils with organic wastes. Report to Congress in response to Section 1461 of the Food and Agriculture Act of 1977 (P.L. 950113). USDA, Washington, DC.

U.S. Department of Agriculture. 1972-1994. Agricultural statistics. U.S. Gov. Print. Office, Washington, DC.

van Kessel, C., R.E. Farrell, and D.J. Pennock. 1994. Carbon-13 and nitrogen-15 natural abundance in crop residues and soil organic matter. Soil Sci. Soc. Am. J. 58:382-389.

Wayne, W.J. 1991. Paleoclimates in the Northern Great Plains. p. 469470. In R.G. Morrison (ed.) Quaternary nonglacial geology: Conterminous U.S. Vol. K2. Geol. Soc. Am., Boulder, CO.

Wedin, D.A., L.L. Tieszen, B. Dewey, and J. Pastor, 1995. Carbon isotope dynamics during grass decomposition and soil organic matter formation. Ecology 76:1383-1392.

Wilhelm, W.W., L.N. Mielke, and C.R. Fenster. 1982. Root development of winter wheat as related to tillage practices in western Nebraska. Agron. J. 74:85-88.

Woomer, P.L., C.A. Palm, N. Karanja, J.N. Quershi, and J. KottoSame. 1997. Carbon sequestration and organic resource management in African smallholder agriculture. In R. Lal et al. (ed.) Soil processes and the carbon cycle. Adv. Soil Sci. CRC Press, Boca Raton, FL (in press).

Wright, H.E., Jr. 1970. Vegetational history of the Central Plains. p. 157-172. In W. Dort and J.K. Jones (ed.) Pleistocene and recent environments of the Central Plains. Dep. of Geol., Univ of Kansas Spec. Publ. 3. Univ. Press of Kansas, Lawrence.

Wright, H.E., Jr. 1983. Introduction. p. xi-xvii. In H.E. Wright, Jr. (ed). Late quaternary environments of the United States. Vol. 2. Univ. of Minnesota Press, Minneapolis. 